УДК 378.141:373.3

DOI https://doi.org/10.32782/apv/2021.3.12

Алла КРАМАРЕНКО

доктор педагогічних наук, професор, Бердянський державний педагогічнийуніверситет, вул. Шмідта. 4, м. Бердянськ, Запорізька область, Україна, 71100

ORCID: 0000-0003-3922-4979

Бібліографічний опис статті: Крамаренко, А. (2021). Застосування технології критичного мислення в процесі вивчення здобувачами початкової освіти курсу «Я досліджую світ». Acta Paedagogica Volynienses, 3, 76-82, doi: https://doi.org/10.32782/apv/2021.3.12

\title{
ЗАСТОСУВАННЯ ТЕХНОЛОГІЇ КРИТИЧНОГО МИСЛЕННЯ В ПРОЦЕСІ ВИВЧЕННЯ ЗДОБУВАЧАМИ ПОЧАТКОВОЇ ОСВІТИ КУРСУ «Я ДОСЛІДЖУЮ СВІТ»
}

\begin{abstract}
У статті розглядається питання застосування технології критичного мислення в проиесі вивчення здобувачами початкової освіти курсу «Я досліджую світ». Автор акиентує на процесі модернізаиії Нової української школи та впровадженні інтегрованого курсу «Я досліджую світ», пропонує приклади застосування методів критичного мислення під час викладання запропонованого курсу. Зазначається, щуо технологія критичного мислення, ї̈ застосування під час викладання інтегрованого курсу «Я досліджую світ» $є$ досить актуальною в практиці вчителів, а практико орієнтовні завдання в иьому контексті вимагають додаткового розкриття в контексті інноваційного змісту предмета. Розглянуто детально методи розвитку критичного мислення в здобувачів початкової освіти на уроках курсу «Я досліджую світ». Підкреслено, щзо інтеграція численних освітніх галузей, а саме природничої, громадянської, історичної, соціальної та здоров 'язбережувальної освітніх галузей в курсі «Я досліджую світ», передбачає трунтовної підготовки з боку вчителя до проведення таких уроків (до того ж за різними програмами НУШ-1 та НУШ-2 інтеграчія представлена дещо по різному). Під час моделювання вищезазначених уроків слід враховувати особливість навчального матеріалу, оскільки досвід свідчить, щзо розробка навчальних занять у цүій технологї вимагає від учителя трунтовної підготовки, особливо у 1 класі. Вважаємо, шьо оптимальним буде використання окремих елементів технології: «Мозкова атака» «Мікрофон», «Гронування», «Джигсоу», «Метод ПРЕС», «Сенкан» тощз. Отже, технологія розвитку критичного мислення дозволяє максимально підвищити ефективність освітнього процесу, дає можливість створити такі умови, коли всі учні залучаються до активної, творчої діяльності, процесу самонавчання, самореалізації, вчаться спілкуватись, співпрацювати, критично мислити, відстоювати свою позицію, адаптує учнів до жсття у суспільстві.
\end{abstract}

Ключові слова: критичне мислення, технологія критичного мислення, курс «Я досліджую світ», Нова українська школа.

\section{Alla KRAMARENKO}

Doctor of Pedagogics, Professor, Berdiansk State Pedagogical University, Schmidta str., 4, Berdiansk, Zaporozhye region, Ukraine, 71100

ORCID: 0000-0003-3922-4979

To cite this article: Kramarenko, A (2021). Zastosuvannia tekhnolohii krytychnoho myslennia v protsesi vyvchennia zdobuvachamy pochatkovoi osvity kursu "Ia doslidzhuiu svit" [Application of critical thinking technology in the process of studying the course "I explore the world" by primary school students]. Acta Paedagogica Volynienses, 3, 76-82, doi: https://doi.org/10.32782/apv/2021.3.12

\section{APPLICATION OF CRITICAL THINKING TECHNOLOGY IN THE PROCESS OF STUDENTS OF PRIMARY EDUCATION OF THE COURSE "I AM EXPLORING THE WORLD"}

The article considers the application of critical thinking technology in the process of studying the course "I explore the world" by primary school students. The author focuses on the process of modernization of the New Ukrainian School and the introduction of an integrated course "I explore the world", offers examples of the application of critical thinking methods in teaching the proposed course. It is noted that the technology of critical thinking, its application in teaching an integrated course "I explore the world" is quite relevant in the practice of teachers, and practice-oriented tasks in this context require additional disclosure in the context of innovative content. Methods for the development of critical thinking 
in primary school students in the lessons of the course "I explore the world" are considered in detail. It is emphasized that the integration of many educational fields, namely natural, civic, historical, social and health education in the course "I explore the world", provides a thorough preparation by the teacher to conduct such lessons (in addition to various NUS programs). 1 and NUS-2 integration are presented somewhat differently). When modeling the above lessons, one should take into account the peculiarity of the educational material, as experience shows that the development of educational classes in this technology requires a thorough training from the teacher, especially in the 1st grade. We believe that it will be optimal to use certain elements of technology: "Brainstorming", "Microphone", "Groning", "Jigsaw", "PRESS Method", "Senkan", etc. Thus, the technology of critical thinking allows to maximize the efficiency of the educational process, allows to create conditions when all students are involved in active, creative activities, self-learning, self-realization, learn to communicate, cooperate, think critically, defend their position, adapts students to life in society.

Key words: critical thinking, technology of critical thinking, course "I explore the world", New Ukrainian school.

Актуальність теми. Філософія освіти зорієнтована на нові виклики сьогодення, які потребують перегляду системи «вчитель - учень навколишнє середовище (Troitska et al, 2019; Troitska, 2015). Сучасна початкова школа орієнтована на формування компетентнісної, креативної особистості здобувача початкової освіти, здатної аналізувати виклики сьогодення, самостійно опановувати новий матеріал, бути відкритої до інновацій в епоху постійних змін в умовах сталого розвитку. Відповідно до формування двох із десяти визначених Концепцією Нової української школи ключових компетентностей - «Компетентності в природничих науках і технологіях» та «Екологічна грамотність і здорове життя» - $€$ одним із завдань навчання курсу «Я досліджую світ» в початковій школі. Перехід початкової освіти від знаннєвої парадигми до компетентнісної потребує цілеспрямованої роботи в системі «вчитель початкової школи - здобувач початкової освіти». Майбутній учитель початкової школи повинен бути готовим до впровадження інноваційних технологій, здатним креативно їх втілювати на практиці (Shabarina et al 2020, pp. 135). Технологія критичного мислення, iї застосування під час викладання інтегрованого курсу «Я досліджую світ» є досить актуальною в практиці вчителів, а практико орієнтовні завдання в цьому контексті вимагають додаткового розкриття в контексті інноваційного змісту предмета.

Аналіз останніх досліджень та публікацій. Державним стандартом 013 ОПП Початкова освіта передбачено формування в майбутніх учителів початкової школи ряда компетенцій, які сприятимуть їх високому професіоналізму (Kramarenko et al, 2017, pp. 189), а активізація когнітивної складової частини їх власної готовності до реалізації реформ НУШ, тільки ефективно впливатиме на процес підвищення рівня конкурентоздатності в єдиному європейському освітньому просторі (Prokopenko et al, 2020). На сучасному етапі модернізації освіти успішно здійснюється реалізація горизонтальної траєкторії навчання «викладач ЗВО - майбутній учитель початкової освіти - вчитель початкової освіти». 3'являється відповідна навчальнометодична література із осучаснення освітнього простору як ЗВО, так й НУШ.

Згідно 3 Концепцією Нової української школи, аналізуючи загальні позиції впровадження технології критичного мислення, О. Пометун представлено навчально-методичний посібник «Нова українська школа : розвиток критичного мислення учнів початкової школи», проте, на нашу думку, не достатньо прикладів із застосування зазначеної технології щодо курсу «Я досліджую світ» (Пометун, 2020). У статті Г.Столяр представлено методи 3 розвитку критичного мислення на уроках «Я досліджую світ», хоча $\epsilon$ неточності iз структурування такого уроку (Столяр, 2021).

Мета дослідження полягає в розкритті питання застосування технології критичного мислення в процесі вивчення здобувачами початкової освіти курсу «Я досліджую світ».

Виклад основного матеріалу дослідження. Аналіз численних публікацій, дає підстави зазначити, що технологія розвитку критичного мислення (ТРКМ) - це проєкт співпраці численних учених та вчителів-практиків усього світу.

За історичною довідкою проєкт був запропонований у 90-ті роки 20 століття американськими вченими К. Мередит, Ч. Темплом та Дж. Стилом як особлива методика навчання, що містить відповідь на питання: «Як вчити мислити?». Американський професор, доброволець програми розвитку критичного мислення Д.Клустер стверджував, що мислити критично можна в будь-якому віці: «Для цього достатньо життєвого досвіду не лише у здобувачів вищої 
освіти, а і в першокласників». Саме здобувач початкової освіти через свій вік відкритий до всього нового, здатний нестандартно мислити та вирішувати ситуації креативно.

Багаточисленні наукові розробки є досить різнобічними (С. Векслер, А. Липкіна, О. Пометун, Л. Рибак, В. Синельников та ін.). Дослідники ставили питання про розвиток уміння здобувача самостійно осмислювати навчальний матеріал, виконувати креативні завдання, робити власні висновки із запропонованого матеріалу, помічати як власні помилки, так і помилки своїх однолітків. Це свідчить, що певні риси критичного мислення доцільно розвивати в початковій ланці освіти. Відповідно, ігнорування означеного положення значно ускладнює цю проблему в більш дорослому віці.

3 метою розвитку критичного мислення в здобувачів початкової освіти необхідно навчити їх самостійно робити висновки та знаходити рішення, аналізувати та спостерігати, шукати пояснення (Komar, Chuchalina et al, 2021, pp. 470).

Аналізуючи та систематизуючи матеріал із представленої проблеми, ми у власній практиці працюємо з майбутніми вчителями початкової освіти БДПУ за авторським підручником «Сучасні технології навчання природничої, громадянської та історичної освітніх галузей в початковій школі» (Крамаренко, 2021). Перед його виданням мали час на апробацію та корегування окремих позицій щодо застосування відповідних технологій в освітньому процесі НУШ.

Так, розвиток критичного мислення здобувачів початкової освіти на уроках курсу «Я досліджую світ» доцільно організовувати у такій послідовності: організація спостереження, стимулювання творчої уяви, розвиток потреби творчості, підтримка позитивних емоцій, виховання вольових рис характеру. 3 метою ефективного формування критичного мислення структура уроку курсу «Я досліджую світ» передбачає три стадії спільної діяльності вчителів та здобувачів початкової освіти: 1) актуалізації (пробудження інтересу до предмета); 2) побудови знань (осмислення матеріалу); 3) рефлексії (узагальнення матеріалу).

Разом із тим у процесі моделювання вищезазначених уроків слід враховувати особли- вість навчального матеріалу, оскільки досвід свідчить, що розробка навчальних занять у цій технології вимагає від учителя грунтовної підготовки, особливо у 1 класі. Вважаємо, що оптимальним буде використання окремих елементів технології: «Мозкова атака», «Мікрофон», «Гронування», «Джигсоу», «Метод ПРЕС», «Сенкан» тощо.

Розглянемо детальніше методи розвитку критичного мислення в здобувачів початкової освіти на уроках курсу «Я досліджую світ». Слід враховувати, що інтеграція численних освітніх галузей, а саме природничої, громадянської, історичної, соціальної та здоров'язбережувальної освітніх галузей в курсі «Я досліджую світ», передбачає грунтовної підготовки з боку вчителя до проведення таких уроків (до того ж за різними програмами НУШ-1 та НУШ-2 інтеграція представлена дещо по різному).

Метод «Мозкова атака» дає змогу групі учнів використовувати свої інтелектуальні можливості для швидкого та ефективного виконання завдання. Зазначений метод спонукає здобувачів початкової освіти проявити уяву та креативність, дає можливість їм вільно висловлювати свої думки. Мета його полягає в тому, щоб зібрати якомога більше ідей щодо певної проблеми. На етапі формулювання ідей забороняється робити будь-які зауваження, критикувати. Педагог повинен постійно заохочувати і направляти хід дискусії, залучати до процесу розв'язування завдання всіх учнів та провести загальний підсумок дискусії. Зазначений метод можна застосовувати наприклад для теми «Забруднення Азовського моря та його наслідки» (застосування краєзнавчого принципу).

Детальніший опис методу й таких елементів технології, як «Мікрофон», «Метод ПРЕС», розкрито в темі 3.1 (Крамаренко, 2021).

«Гронування» (від англ. cluster - скупчення) - малюнкова технологія, суть якої полягає в тому, що посередині аркуша записується чи замальовується основне слово (ідея, тема), а по сторонах від неї фіксуються ідеї (слова, малюнки), певним чином пов'язані 3 ним. Цей метод також відомий під назвою «Асоціативний кущ» - стратегія навчання, яка закликає учнів вільно і відкрито висловлювати свої думки, здійснювати взаємозв'язок між окре- 
мими поняттями, тому, сприяє розвитку соціальних, інформаційних компетенцій, спонукає здобувачів початкової освіти до саморозвитку, самоосвіти, продуктивної діяльності.

Наприклад, на уроці курсу «Я досліджую світ» під час вивчення теми «Рослини» учитель пропонує учням пригадати все, що вони знають про рослинний світ. Проте після відповідей учитель звертає увагу на питання розмноження рослин. Не всі учні можуть відповісти на це питання. Таким чином педагог не лише активізував знання учнів, а й підвів їх до теми уроку.

Перед тим як запропонувати здобувачам початкової освіти технологію «Гронування», вчитель повинен оцінити тему, навчальний текст за такими критеріями: «Чи можна його розбити на елементи?», «Чи легко виділити в тексті змістові одиниці?». Отримані «грона» (як на стадії пробудження інтересу до теми, так і на етапі узагальнення матеріалу) необхідно озвучувати. Згодом слід учити здобувачів початкової освіти обгрунтовувати встановлені між «гронами» зв'язки. Якщо необхідно оцінити значущість кожного «грона», можна замалювати головну гілочку кольоровими олівцями. Із вищевказаного, слід вказати, що в разі використання технології «Гронування» учні вчаться активно сприймати матеріал, співвідносити набуті знання 3 новими. За цією технологію можна закріпити знання здобувачів початкової освіти 3 теми «Жива та нежива природа».

Розглянемо прийом технології розвитку критичного мислення «Сенкан». Назва означеного прийому походить від англ. cinquain вірш, п'ятирядкова строфа. Сенкан у дидактиці початкової школи виступає у різних аспектах: як ефективний засіб розвитку образності мовлення, що дозволяє швидко отримати результат; метод інтегральної освітньої технології; інструмент для синтезу й узагальнення інформації, для розвитку креативності та нестандартного погляду на речі. Слід зазначити, що робота над сенканом дозволяє гармонійно поєднувати елементи інформаційної, діяльнісної та особистісно зорієнтованої педагогічних систем.

Дидактичний сенкан укладається за змістовими та синтаксичними вимогами кожного рядка. Це - п'ятирядковий неримований вірш, що складається з одинадцяти слів. Сенкан створюють за такою схемою:
Перший рядок - тема, один іменник або займенник, який позначає предмет обговорення. Другий рядок - два прикметники або дієприкметники, що описують і характеризують тему. Третій рядок - три дієслова про характерні дії об'єкта. Четвертий рядок складає фраза з чотирьох слів, за допомогою якої висловлюємо особисте враження, розуміння теми. П'ятий рядок вміщує одне слово-резюме (іменник), що являє собою підсумок і висловлює сутність об'єкта.

Наведемо приклад сенкану, який можна скласти до уроку курсу «Я досліджую світ» в початковій школі на тему: «Повітря» (природнича освітня галузь).

\section{Повітря \\ Прозоре, безбарвне \\ Оточує, заповнює, рухається \\ Без повітря життя неможливе \\ Дихання}

Представлений прийом «Сенкан» можна використовувати на уроках курсу «Я досліджую світ» в початковій школі як особливий вид творчого завдання, вправу для групової роботи та форму індивідуальної роботи. Та візуалізація інформації надовго залишається в пам'яті здобувача початкової освіти.

Діаграми Вена використовуються вчителями для розробки діяльності учнів під час порівняння спільних і відмінних рис (аналіз та синтез), будуючи їх для наочного та аргументованого подання результатів своїх навчальних досліджень. Вона будується на основі двох або більше великих кіл, що частково накладаються одне на одне і посередині утворюють спільний простір. Їх можна також подати у різних кольорах. Цей прийом допомагає зіставити ідеї, образи, поняття. У колах зазначаються відмінні риси, а у вільному просторі, що утворився від накладання, записуються спільні риси.

Отже, технологія розвитку критичного мислення дозволяє максимально підвищити ефективність освітнього процесу, дає можливість створити такі умови, коли всі учні залучаються до активної, творчої діяльності, процесу самонавчання, самореалізації, вчаться спілкуватись, співпрацювати, критично мислити, відстоювати свою позицію, адаптує учнів до життя у суспільстві.

Технологія розвитку критичного мислення здобувачів початкової освіти буде ефективною 
у поєднанні з інтерактивними методами і прийомами групового і кооперативного навчання. Як приклад навчальних занять 3 курсу «Я досліджую світ» за технологією розвитку критичного мислення, наводимо фрагменти розробок уроків з теми корисних копалин.

\section{Тема: «Що таке гірські породи?» Методика «Мозкова атака»}

1 етап. Актуалізація життєвого досвіду учнів. Учитель: Чи бачили ви кам'яне вугілля? На аркушах паперу, які лежать перед вами, запишіть усе, що ви знаєте про цю корисну копалину. (Учні працюють самостійно).

2 етап. Робота в парах.

Учитель: Використовуючи свої записи, розкажіть своєму товаришеві по парті все, що ви знаєте про кам'яне вугілля. (Учні вчаться самостійно встановлювати рівень власних знань).

3 етап. Колективна робота. Узагальнення знань. Складання таблиці.

Учитель: Поділіться з нами тим, що ви знаєте. (Учні називають, а вчитель записує все на дошиі без коментувань, розмімуючи учнівські відомості у таблиию).

Властивості Використання Добування

\section{Утворення}

чорне опалення шахти тверде крихке

4 етап. Читання тексту 3 використанням інтерактивної системи позначок.

Учитель: Ми з вами визначили, що нам відомо про цю корисну копалину, а зараз перечитаємо текст підручника 3 використанням інтерактивної системи позначок. Для цього візьміть прості олівці. Знаком «+» ми будемо позначати матеріал, який ми знали; знаком «-» - який не знали; «!» - мали неправильні уявлення. Текст читається частинами та робляться відповідні позначки. Така робота активізує розумову діяльність здобувачів початкової освіти, сприяє встановленню причино-наслідкових зв'язків.

5 етап. Систематизація знань.

Учитель: Про що нове ми дізналися з тексту? Запишемо ці відомості до таблиці. Використовуючи матеріал таблиці, складемо розповідь про кам'яне вугілля.

$$
\text { Методика «T-схема» }
$$

Узагальнення отриманих кометенцій. Це багатоцільовий організатор для запису бінарних «так-ні». Учні вчаться порівнювати, аналізувати, робити висновки.

Тема: «Що таке гірські породи?»

Учитель: Які ви знаєте корисні копалини, що видобуваються в нашій місцевості?

Діти: В нашій місцевості видобувається глина, марганцева руда, вапняк, граніт.

Учитель: Яким способом вони видобуваються?

Діти: Вони видобуваються відкритим способом.

Учитель: Сторінку зошита поділіть на дві частини. Зверху лівого стовпчика запишіть слово «за», а зверху правого - «проти». Подумайте і запишіть у лівий стовпчик під словом «за» переваги у видобуванні корисних копалин відкритим способом (кар'єри), а у правий - під словом «проти» - недоліки порівнюючи з видобуванням їх закритим способом (шахти).

Діти працюють самостійно, у їх зошитах з'являються такі записи:

\begin{tabular}{|c|c|}
\hline 3a & Проти \\
\hline & \\
\hline
\end{tabular}

Слід зазначити, що серію авторських статей в журналі «Учитель початкової школи» запропоновано як вчителям початкової школи, так і студентам 3 метою використання вже апробованого дидактичного матеріалу 3 технології розвитку критичного мислення на уроках «Я досліджую світ». Саме за статтю «Природничо-методичний аспект ознайомлення учнів 3 унікальними місцями України» отримано грамоту як кращий матеріал в номінації з впровадження технологій з природничої освітньої галузі в початковій школі (Крамаренко, 2019).

Висновки i перспективи подальших досліджень. Отже, запропоновані завдання для уроків курсу «Я досліджую світ» в початковій школі дозволяють підвищити рівень критичної рефлексії здобувачів початкової школи у процесі їх розв'язання. В перспективних розробках плануємо деталізувати завдання 3 курсу «Я досліджую світ» із застосуванням здоров'язбережувальних технологій. 


\section{ЛITЕРАТУРА:}

1. Troitska T.S., Krylova A.M., Taranenko G.G., Troitska E.M., Popravko O.V. Historical reconstruction of the reproduction of axiology of nature in ukrainian philosophical tradition: methodological reference points. History, philosophy, archaeology, history of art, performing and visual arts, architecture and design, literature and poetry, language and linguistics: 6th SWS International Scientific Conference on Arts and Humanities, (Albena, 26 August-1 September, 2019), 6 (1). Pp. 106-112.

2. Troitska O. M. Conceptual foundations of dialogue idea impromentation into cultural educational space. Canadian scientific journal International multidisciplinary scientific Journal. 2015. Issue 1. Pp. 87-92.

3. Marharyta Shabarina, Khrystyna Verbytska, Valentyna Vitiuk, Vadym Shemchuk, Eduard Saleychuk. Development of Pedagogical Creativity of Future Teachers of Primary School By Means of Innovative Education Technologies. Revista Românească pentru Educaţie Multidimensională. 2020, Vol. 12, Issue 4. Pp. 137-155.

4. Kramarenko Alla, Horbenko Olena, Syladii Ivan. Pedagogy Students' Professional Competence Formation. Наука і освіта (Science and Education). 2017. № 10. Pp. 188-193.

5. Alona Prokopenko, Alla Vozniuk, Hennadii Leshchenko, Liliya Manchulenko, Alla Kramarenko, Oksana Mondich. Activization of Cognitive Activity of Students in Higher Education Institutions. Systematic Reviews in Pharmacy. Vol. 11, Issue 10, Oct-Nov 2020. pp. 144-146. doi:10.31838srp.2020.10.24.

6. Пометун О.І. Нова українська школа : розвиток критичного мислення учнів початкової школи : навч.-метод. посіб. Київ : Видавничий дім «Освіта», 2020. 192 с.

7. Столяр Г. Розвиток критичного мислення молодших школярів на уроках із предмету «Я досліджую світ». 2021. URL: https://ojs.ukrlogos.in.ua/index.php/conferences/article/view/11225/10530

8. Komar O.A., Chuchalina Y.M., Kramarenko A.N., Torchynska T.A., Shevchuk I.V. Agile approach in training future primary school teachers for resolving complex pedagogical situation. International Electronic Journal of Elementary Education. March 2021, Volume 13, Issue 4, pp. 469-477. doi:10.26822/iejee.2021.205

9. Крамаренко Алла. Сучасні технології навчання природничої, громадянської та історичної освітніх галузей в початковій школі: навч. посіб. для здобувачів вищої освіти другого освітнього ступеню ОПП Початкова освіта. Мелітополь: Видавничий будинок Мелітопольської міської друкарні, 2021. 316 с.

10. Крамаренко А.М. Природничо-методичний аспект ознайомлення учнів з унікальними місцями України. Учитель початкової школи. 2019. № 6. С. 13-17.

\section{REFERENCES:}

1. Troitska, T.S. \& Krylova, A.M. \& Taranenko, G.G. \& Troitska, E.M. \& Popravko, O.V. (2019). Historical reconstruction of the reproduction of axiology of nature in ukrainian philosophical tradition: methodological reference points. History, philosophy, archaeology, history of art, performing and visual arts, architecture and design, literature and poetry, language and linguistics: 6th SWS International Scientific Conference on Arts and Humanities, (Albena, 26 August-1 September, 2019), 6 (1). Pp. 106-112. (in English).

2. Troitska, O. M. (2015). Conceptual foundations of dialogue idea impromentation into cultural educational space. Canadian scientific journal International multidisciplinary scientific Journal. 2015. Issue 1. Pp. 87-92. (in English).

3. Marharyta Shabarina \& Khrystyna Verbytska \& Valentyna Vitiuk \& Vadym Shemchuk \& Eduard Saleychuk (2020). Development of Pedagogical Creativity of Future Teachers of Primary School By Means of Innovative Education Technologies. Revista Românească pentru Educaţie Multidimensională. Vol. 12, Issue 4. Pp. 137-155. (in English).

4. Kramarenko Alla \& Horbenko Olena \& Syladii Ivan (2017). Pedagogy Students' Professional Competence Formation. Наука і освіта (Science and Education). № 10. Pp. 188-193. (in English).

5. Alona Prokopenko \& Alla Vozniuk \& Hennadii Leshchenko \& Liliya Manchulenko \& Alla Kramarenko \& Oksana Mondich (2020). Activization of Cognitive Activity of Students in Higher Education Institutions. Systematic Reviews in Pharmacy. Vol. 11, Issue 10, Oct-Nov pp. 144-146. doi: 10.31838srp.2020.10.24(in English).

6. Pometun O. I. (2020) Nova ukrainska shkola : rozvytok krytychnoho myslennia uchniv pochatkovoi shkoly [New Ukrainian school: development of critical thinking of primary school students]. Kyiv : Vydavnychyi dim «Osvita», 192 p. (in Ukrainian)

7. Stoliar H. (2021). Rozvytok krytychnoho myslennia molodshykh shkoliariv na urokakh iz predmetu «Ia doslidzhuiu svit» [Development of critical thinking of junior schoolchildren in lessons on the subject «I explore the world»]. URL: https://ojs.ukrlogos.in.ua/index.php/conferences/article/view/11225/10530 [in Ukrainian].

8. Komar O.A., Chuchalina Y.M., Kramarenko A.N., Torchynska T.A., Shevchuk I.V. Agile approach in training future primary school teachers for resolving complex pedagogical situation. International Electronic Journal of Elementary Education. March. 2021, Volume 13, Issue 4, pp. 469-477. doi:10.26822/iejee.2021.205(in English). 
9. Kramarenko Alla (2021). Suchasni tekhnolohii navchannia pryrodnychoi, hromadianskoi ta istorychnoi osvitnikh haluzei v pochatkovii shkoli: navch. posib. dlia zdobuvachiv vyshchoi osvity druhoho osvitnoho stupeniu OPP Pochatkova osvita. [Modern technologies of teaching natural, civic and historical educational branches in primary school: textbook. way. for applicants for higher education of the second educational degree OPP Primary education]. Melitopol: Vydavnychyi budynok Melitopolskoi miskoi drukarni, 316 p. [in Ukrainian].

10. Kramarenko A.M. (2019). Pryrodnycho-metodychnyi aspekt oznaiomlennia uchniv z unikalnymy mistsiamy Ukrainy. [Natural and methodological aspect of acquainting students with the unique places of Ukraine] Uchytel pochatkovoi shkoly. № 6. Pp. 13-17. [in Ukrainian]. 